Document downloaded from:

http://hdl.handle.net/10251/160838

This paper must be cited as:

De-Miguel-Molina, B.; Boix Domenech, R.; De-Miguel-Molina, M. (2019). Analysing innovation in museums through qualitative comparative analysis. Knowledge Management Research \& Practice. 17(2):213-226. https://doi.org/10.1080/14778238.2019.1601505

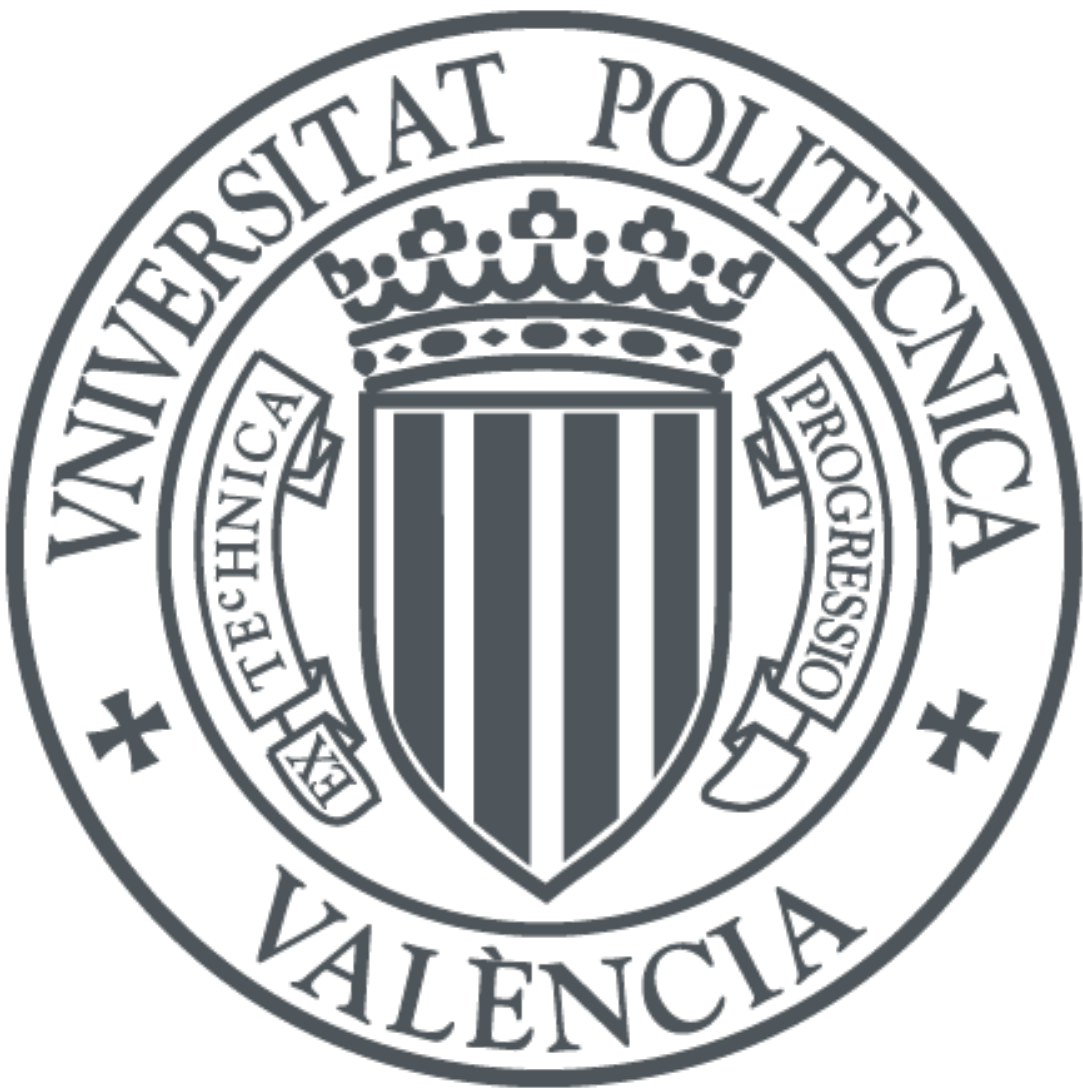

The final publication is available at

https://doi.org/10.1080/14778238.2019.1601505

Copyright Taylor \& Francis

Additional Information

This is an Accepted Manuscript of an article published by Taylor \& Francis in Knowledge Management Research \& Practice, on 22/04/2019, available online:

https://www.tandfonline.com/doi/abs/10.1080/14778238.2019.1601505 
This is an Accepted Manuscript of an article published by Taylor \& Francis in Knowledge Management Research \& Practice, on 22/04/2019, available online: https://www.tandfonline.com/doi/abs/10.1080/14778238.2019.1601505

Please, cite as: Blanca de Miguel Molina, Rafael Boix Domenech \& María de Miguel Molina (2019) Analysing innovation in museums through qualitative comparative analysis, Knowledge Management Research \& Practice, 17:2, 213-226, DOI: 10.1080/14778238.2019.1601505

\title{
Analysing innovation in museums through Qualitative Comparative Analysis
}

\author{
Blanca de-Miguel-Molina ${ }^{1 *}$, Rafael Boix ${ }^{2}$, María de-Miguel-Molina ${ }^{1}$ \\ ${ }^{1}$ Department of Management, Universitat Politècnica de València, Valencia, Spain. \\ ${ }^{2}$ Department of Applied Economics II - Economic Structure, Universitat de València, \\ Valencia, Spain.
}

\begin{abstract}
The aim of this paper is to analyse innovation in the processes undertaken by museums in the conservation and restoration of artworks. Information from 90 conservation and restoration departments from museums in 43 countries was analysed using Qualitative Comparative Analysis. Two theoretical concepts knowledge bases (analytical, synthetic, symbolic) and modes of innovations (STI, DUI) were used to define necessary and sufficient conditions which explain innovation in artwork restoration. Two important results were obtained from the analysis; the first indicated that innovation was explained by the combination of symbolic and analytical knowledge bases (unrelated variety), and high innovation performance was also explained by the related variety in the analytical knowledge base. The second result revealed that innovation is higher when museums cooperate simultaneously with partners using the two modes of innovation.
\end{abstract}

Keywords: museums; innovation; knowledge bases; modes of innovation

Subject classification codes: O3, M2, L8, Z1

\section{Introduction}

What determines museum innovation in artwork conservation and the degree of innovation?

In this paper, two theoretical concepts, the knowledge bases approach and the modes of innovation theory, were used to obtain necessary and sufficient conditions that explained why museums innovate in artwork conservation processes. Both theories refer to the sources the organisations use to obtain knowledge and the channels used to transmit this knowledge (Grillitsch \& Trippl, 2014).

The research has focused on analysing which knowledge bases (analytical, synthetic, symbolic) generate the greatest number of innovations. However, as 
This is an Accepted Manuscript of an article published by Taylor \& Francis in Knowledge Management Research \& Practice, on 22/04/2019, available online: https://www.tandfonline.com/doi/abs/10.1080/14778238.2019.1601505

Please, cite as: Blanca de Miguel Molina, Rafael Boix Domenech \& María de Miguel Molina (2019) Analysing innovation in museums through qualitative comparative analysis, Knowledge Management Research \& Practice, 17:2, 213-226, DOI: 10.1080/14778238.2019.1601505

Grillitsch, Martin, \& Srholec (2017) pointed out, there are few empirical studies which specify the combination of knowledge bases that generates higher innovation. Some authors state that the analytical base gives better results (Pina \& Tether, 2016), although the majority of studies indicate that a combination of bases, that is, unrelated variety, gives the best outcome (Grillitsch et al., 2017). Literature about knowledge bases has stated that, in creative industries, symbolic and synthetic bases coexist in sectors such as architecture, music and design (Asheim \& Hansen, 2009; Klein, 2011, Van Tuijl \& Carvalho, 2014). Nevertheless, there are few examples covering a mix of symbolic and analytical bases in these industries (Plum \& Hassink, 2014). Additionally, there are even fewer studies including related variety of knowledge bases that analyse their impact on innovation (Květoň \& Kadlec, 2018).

Recent literature about modes of innovation has also focused on which mode (STI, DUI or a combination) is more effective (Apanasovich, 2016). Studies give different results when the two modes are analysed individually, although they did find that the combination of both modes generates a larger number of innovations (Fitjar \& Rodríguez-Pose, 2013; González-Pernía, Parrilli, \& Peña-Legazkue, 2015; Parrilli \& Alcalde Heras, 2016). Conversely, studies about creative industries have centred on analysing external sources of information (Protogerou, Kontolaimou, \& Caloghirou, 2017) and social networks (Plum \& Hassink, 2014). The reason might be that the conceptualisation of symbolic knowledge has found that cooperation with other professionals and firms relies mainly on obtaining information about the market (Plum $\&$ Hassink, 2014). Studies in the same vein as knowledge bases that consider a variety of partners in the same mode of innovation are rare.

In addition, studies focusing on the determinants of innovation in creative industries remain scarce (Protogerou et al., 2017), in particular when using or combining knowledge bases and innovation mode approaches.

This paper tries to cover these gaps by explaining innovation in a creative industry (artwork restoration) as a result of the combination and variety of knowledge bases and innovation modes. A contribution of this paper is the use of Qualitative Comparative Analysis (QCA) methodology. The majority of studies centring on these two theoretical approaches use methodology regression analysis. The advantage of using QCA is that it enables the definition of necessary and sufficient causal conditions to explain an output, which, in our case, was innovation in a creative industry, i.e. the conservation and restoration of artworks. Causal conditions include a combination of analytical and symbolic knowledge bases (unrelated variety), that few examples cover in creative industries (Plum \& Hassink, 2014; Květoň \& Kadlec, 2018), as well as related variety in the shape of the diversity of qualifications within a knowledge base. Moreover, causal conditions also analyse the role of STI and DUI modes in creative industries, with a "cooperation for innovation" approach that is also difficult to find in 
This is an Accepted Manuscript of an article published by Taylor \& Francis in Knowledge Management Research \& Practice, on 22/04/2019, available online: https://www.tandfonline.com/doi/abs/10.1080/14778238.2019.1601505

Please, cite as: Blanca de Miguel Molina, Rafael Boix Domenech \& María de Miguel Molina (2019) Analysing innovation in museums through qualitative comparative analysis, Knowledge Management Research \& Practice, 17:2, 213-226, DOI: 10.1080/14778238.2019.1601505

studies on creative industries. Finally, the diversity of partners in each mode of innovation was also covered.

The paper is structured as follows. After this introduction, Section 2 summarises the theories about knowledge bases and modes of innovation, including the hypotheses defined. Sections 3 and 4 then present the empirical analysis about innovation in restoration and conservation departments in museums. Our conclusions are revealed in Section 5.

\section{Knowledge bases, STI/DUI interactions and creative industries}

\section{The role of knowledge bases in creative industries}

Knowledge bases are "types of knowledge used as input in knowledge creation and innovation processes" (Asheim, Boschma, \& Cooke, 2011). The categorisation of knowledge bases starts with the distinction made by Laestadius (2002) between analytical and synthetic knowledge bases. He used natural and engineering sciences to illustrate the difference between the two types of knowledge, indicating that natural sciences (bio-industries) are theory-driven whereas engineering sciences (the pulp and paper industry) are trial-driven. Following this division, Asheim \& Coenen (2005) explained that innovation in firms and industries depends on analytical (science-based) and synthetic (engineering-based) knowledge bases. Then, Asheim (2007) added a third variation, known as the symbolic (creativity-based) knowledge base. This taxonomy is also called SAS -synthetic, analytical, symbolic (Manniche, 2012).

In an analytical base, scientific knowledge is highly relevant and is generated in the Research and Development (R\&D) departments of firms, universities and other research institutions. The output from this knowledge is documented and codified, and leads to radical innovations in products and/or processes, scientific discoveries and technological inventions (Asheim \& Coenen, 2005; Asheim, 2007; Asheim \& Hansen, 2009; Moodysson, Coenen, \& Asheim, 2008).

In a synthetic base, knowledge is gained through "learning by doing" when companies solve problems in conjunction with clients and suppliers, and results come in the shape of incremental innovation in existing products and services (Asheim \& Coenen, 2005; Asheim, 2007; Asheim \& Hansen, 2009; Moodysson et al., 2008).

In a symbolic base, knowledge is acquired through practice and interaction in the different stages of the creative process. This process is focused on creating new ideas and images and is based on temporary projects in which partners have a complementary specialisation (Asheim, 2007; Asheim \& Hansen, 2009). The aim of working together on symbolic knowledge bases, with direct competitors, is to obtain information about 
This is an Accepted Manuscript of an article published by Taylor \& Francis in Knowledge Management Research \& Practice, on 22/04/2019, available online: https://www.tandfonline.com/doi/abs/10.1080/14778238.2019.1601505

Please, cite as: Blanca de Miguel Molina, Rafael Boix Domenech \& María de Miguel Molina (2019) Analysing innovation in museums through qualitative comparative analysis, Knowledge Management Research \& Practice, 17:2, 213-226, DOI: 10.1080/14778238.2019.1601505

the market and technologies, although studies indicate that the market is the most highly demanded piece of information (Plum \& Hassink, 2014).

In addition to the categorisation of the bases, the literature has focused on three other aspects: the first is the empirical measurement of the bases, the second is whether firms and institutions are composed of a unique knowledge base or of a combination of bases, whilst the third relates to the impact of knowledge bases on innovation performance and on different types of innovation.

The works covering knowledge bases in creative industries include studies on the video game industry (Plum \& Hassink, 2014), design (Van Tuijl \& Carvalho, 2014; Pina \& Tether, 2016), architecture (Pina \& Tether, 2016), music (Klein, 2011) and the media (Martin \& Moodysson, 2011).

Table 1 synthesises the main approaches to the measurement of knowledge bases in the literature. Asheim \& Hansen (2009) stated that knowledge bases are reflected in education and work experience. To indicate which knowledge base relates to each type of education, they drew up a list of different occupations. In this list, they included engineers and architects in the synthetic knowledge base, and considered physicists and chemists as belonging to the analytical knowledge base. Writers, creative and performing artists were included in the symbolic knowledge base. Martin (2012) also used occupation as the variable to measure knowledge bases. He defined groups of occupations which were likely to be involved in innovation, organising them into those that were science-based (analytical), engineering-based (synthetic) and arts-based (symbolic). Some authors prefer to use occupation data arguing that there might be a mismatch between career and educational background (Manniche, Moodysson, \& Testa, 2017).

Other studies consider that the primary rationale of the three knowledge bases (science, engineering and creativity-based) can be explained by formal qualifications and university degrees, although they indicate that these are less necessary in creative industries (Plum \& Hassink, 2014). Müller, Rammer, \& Trüby (2009) used data from the academic subjects of graduate employees in creative industries to analyse product and process innovations. They found a positive relationship between different academic backgrounds (natural sciences, maths, computer science, engineering) and process and product innovations and in-house R\&D. Studies not focused on creative industries show that firms whose employees come from more diverse backgrounds are more successful in introducing radical innovations (Mohammadi, Broström, \& Franzoni, 2017).

Furthermore, Asheim \& Hansen (2009) stated that some occupations share more than one knowledge base, as occurs with architects, who share synthetic and symbolic bases. This example is not the only one we have found which designates a creative industry that combines two knowledge bases. For example, Klein (2011) pointed out that the symbolic and synthetic bases also coexist in the music industry. 
This is an Accepted Manuscript of an article published by Taylor \& Francis in Knowledge Management Research \& Practice, on 22/04/2019, available online: https://www.tandfonline.com/doi/abs/10.1080/14778238.2019.1601505

Please, cite as: Blanca de Miguel Molina, Rafael Boix Domenech \& María de Miguel Molina (2019) Analysing innovation in museums through qualitative comparative analysis, Knowledge Management Research \& Practice, 17:2, 213-226, DOI: 10.1080/14778238.2019.1601505

Additionally, we found studies that considered sources of information as a way to identify knowledge bases. For example, Herstad, Aslesen, \& Ebersberger (2014) believe that the analytical knowledge base can be identified because it uses scientific sources whereas synthetic knowledge uses non-scientific sources, such as customers, suppliers and competitors.

\section{HERE TABLE 1, please}

A second question is whether creative industries are composed of single or combined knowledge bases. This question reflects the evolution in knowledge base literature that has moved from an approach that explains each base towards a more recent line of work which focuses on detecting which combinations of knowledge bases generate better innovation results, as pointed out by Boschma (2018). Initially, some authors indicated a prevalence of one knowledge base in a particular sector or industry (Květoň \& Kadlec, 2018). For example, Asheim \& Hansen (2009) stated that the analytical base was dominant in biotechnology and nanotechnology, while the synthetic base was the primary base in engineering activities.

In creative industries, such as the media, advertising, and design industries, it is assumed that the symbolic base predominates over the other two (Asheim \& Hansen, 2009; Martin \& Moodysson, 2011). However, Pina \& Tether (2016), in their analysis of different KIBS, concluded that there were more firms with synthetic knowledge as their primary base in architecture, engineering, and software. Conversely, there were more firms with symbolic knowledge as their key base in specialist design. The reason for this may lie in the fact that creative sectors are more diverse leading to differences in their primary knowledge bases.

Indeed, other studies have stated that both creative and non-creative industries and firms are made up of more than one knowledge base (Asheim, 2007; Asheim \& Hansen, 2009; Manniche, 2012; Grillitsch et al., 2017; Moodysson et al., 2018; McIver, Fitzsimmons, \& Lengnick-Hall, 2019). For example, some authors indicate that in creative industries there is a combination of symbolic and synthetic bases (Asheim \& Hansen, 2009; Klein, 2011; Plum \& Hassink, 2014; Van Tuijl \& Carvalho, 2014), although there are few references to a mix of analytical and symbolic bases (Plum \& Hassink, 2014; Květoň \& Kadlec, 2018). In the last two years, some studies have indicated that the three knowledge bases might appear together in creative industries (Table 2). However, these works specify that a mix does not imply equal importance for each base. They also indicate that the prevalent base might change over the years (Ingstrup, Jensen, \& Christensen, 2017). The importance of considering the combination of bases is that it has been proved to increase the innovation performance of firms (Tödtling \& Grillitsch, 2015). Table 2 shows which combinations of 
This is an Accepted Manuscript of an article published by Taylor \& Francis in Knowledge Management Research \& Practice, on 22/04/2019, available online: https://www.tandfonline.com/doi/abs/10.1080/14778238.2019.1601505

Please, cite as: Blanca de Miguel Molina, Rafael Boix Domenech \& María de Miguel Molina (2019) Analysing innovation in museums through qualitative comparative analysis, Knowledge Management Research \& Practice, 17:2, 213-226, DOI: 10.1080/14778238.2019.1601505

knowledge bases have been identified for different creative industries in previous works.

\section{HERE TABLE 2, please}

The third question is how do knowledge bases influence the innovation performance of firms. Here we differentiate between the effect of individual and combined knowledge bases. In the first case, the analysis would focus on which base has a higher impact on innovation whereas in the second case the study would have to detect which combination of bases delivers higher innovation performance. In studies focused on non-creative industries and on individual knowledge bases, the results suggest that the analytical base has a stronger impact on innovation than the synthetic and symbolic bases. For example, Pina \& Tether (2016) found that firms in which the analytical knowledge base was dominant were more likely to innovate (regarding varieties of innovation). Moreover, they also found that firms with a dominant symbolic base were less likely to innovate. Grillitsch et al. (2017) also found that the symbolic base had a poor effect on innovation when it appeared on its own. Herstad et al. (2014), in their study on Norway, found that firms operating with synthetic knowledge were less likely to engage in joint innovation. The higher impact of the analytical base might be explained by its actual concept, which links this base to R\&D activities (Asheim, 2007; Asheim \& Hansen, 2009), while this is not the case for the synthetic base.

However, the Oslo Manual (OECD/Eurostat, 2018) indicates that creative works do not meet all of the five conditions in the Frascati Manual (2015), such as uncertain outcome so they cannot be considered as R\&D activities. In spite of this, literature has proved that non-R\&D activities can also lead to innovation (Hervás-Oliver, Sempere-Ripoll, Boronat-Moll, \& Rojas, 2015; Hervás-Oliver, Sempere-Ripoll, Boronat-Moll, \& RojasAlvarado, 2018).

On the other hand, studies have proved that a combination of knowledge increases the innovation performance of firms (Tödtling \& Grillitsch, 2015). Grillitsch et al. (2017) analysed the combination of knowledge bases and concluded that when there is a combination of analytical and symbolic bases, innovation is higher than when there is solely an analytical base. They also stated that the synthetic base produces a higher impact on innovation when it is combined with a mainly analytical base or a symbolic base. Therefore, the combination of knowledge bases (unrelated variety) gives better innovation results than a single base, even if it is the analytical one. Moreover, they concluded that only the analytical knowledge base benefits from related variety in a region (diversity of occupations in the same knowledge base). Other recent studies have indicated that both unrelated and related varieties (variety across and within knowledge bases) are important to explain innovation at company and regional level (Boschma, 2018; Květoň \& Kadlec, 2018). 
This is an Accepted Manuscript of an article published by Taylor \& Francis in Knowledge Management Research \& Practice, on 22/04/2019, available online: https://www.tandfonline.com/doi/abs/10.1080/14778238.2019.1601505

Please, cite as: Blanca de Miguel Molina, Rafael Boix Domenech \& María de Miguel Molina (2019) Analysing innovation in museums through qualitative comparative analysis, Knowledge Management Research \& Practice, 17:2, 213-226, DOI: 10.1080/14778238.2019.1601505

As studies have shown, creative industries tend to combine symbolic with synthetic and analytical bases (see Table 2), whilst papers on other sectors concluded that the analytical base is more likely to generate innovation (for example, Pina \& Tether (2016) and Grillitsch et al., 2017). Therefore, we can state that:

Hypothesis 1. Museums are more likely to innovate if there is a combination of analytical and symbolic knowledge (unrelated variety) in their restoration and conservation departments rather than if there is only a symbolic base (unique variety).

Hypothesis 2. Museums are more likely to innovate if there is related variety in the analytical knowledge base rather than if related variety appears only in the symbolic base.

\section{STI/DUI modes of innovation in creative industries}

The notion of Science, Technology and Innovation (STI) and Doing, Using and Interacting (DUI) modes of innovation was developed by Jensen, Johnson, Lorenz, \& Lundvall (2007). The former is based on the production and use of scientific and technical knowledge, whereas the latter relies on learning by doing, using and interacting. Literature has offered advances in explaining innovation in the light of each mode separately, the combination of both, and their impact on different types of innovation (product, process, radical and incremental).

There are connections between knowledge bases and the two modes of innovation (Table 3). For example, Asheim \& Coenen (2005) established that in the analytical knowledge base, scientific knowledge is highly relevant and companies tend to work with universities and other research institutions. Moreover, when they identified the synthetic knowledge base, they indicated that knowledge is obtained on the job by doing, using and interacting (DUI), and cooperation occurs across the value chain with suppliers and customers. Other authors have also established links between analytical knowledge and the STI mode, and between synthetic knowledge and the DUI mode (Fitjar \& Rodríguez-Pose, 2013; Grillitsch \& Trippl, 2014; Herstad et al., 2014; Tödtling \& Grillitsch, 2015; Parrilli \& Alcalde-Heras, 2016; Aslesen \& Pettersen, 2017; Hauge, Kyllingstad, Maehle, \& Schulze-Krogh, 2017; Květoň \& Kadlec, 2018). Meanwhile, symbolic knowledge has been associated with the DUI mode (Fitjar \& Rodríguez-Pose, 2013; Hauge et al., 2017), although some creative activities such as artwork restoration also make intensive use of the STI mode related to chemicals, biology, physics and the science of materials.

The majority of studies that use the innovation modes approach refer to cooperation for innovation. As Fitjar \& Rodríguez-Pose (2013) pointed out, "interactions are at the base of the STI and DUI modes of innovation". Isaksen \& Tripple (2017) cited five types of knowledge-sourcing which include cooperating with 
This is an Accepted Manuscript of an article published by Taylor \& Francis in Knowledge Management Research \& Practice, on 22/04/2019, available online: https://www.tandfonline.com/doi/abs/10.1080/14778238.2019.1601505

Please, cite as: Blanca de Miguel Molina, Rafael Boix Domenech \& María de Miguel Molina (2019) Analysing innovation in museums through qualitative comparative analysis, Knowledge Management Research \& Practice, 17:2, 213-226, DOI: 10.1080/14778238.2019.1601505

other actors (customers, suppliers and universities). This is the type of knowledge source analysed in literature about the STI and DUI modes, which differentiates between cooperating with different agents using the STI mode (universities and research institutes) and the DUI mode (customers, suppliers, and competitors) to influence innovation performance. The STI mode has R\&D as its core activity, and companies look to cooperate with external actors who use this type of activity (Fitjar \& RodríguezPose, 2013; Teixeira, Mota Veiga, \& Abreu Fernandes, 2019). Since the Oslo Manual does not consider that creative work involves R\&D activities (OECD/Eurostat, 2018), creative industries could cooperate with STI actors to obtain science-based knowledge (Apanasovich, 2016).

Do STI and DUI modes impact differently on product and process innovations? Initially, we need to point out that not all of the studies cover both types of innovation. For example, Jensen et al. (2007) took into account product and service innovation, but did not contemplate process innovation. Their analysis indicated that a combination of STI and DUI modes generated more product/service innovations. Fitjar \& RodríguezPose (2013) obtained different results for products and processes in terms of the modes of innovation. They found that the DUI mode contributed more to both product and process innovation through supplier cooperation, whereas the DUI mode only produced product innovation with customers. In the STI mode, they found more probabilities for product innovation when firms cooperated with universities and more probabilities for process innovation when cooperation occurred with research institutes. Therefore, both the DUI and STI modes incentivise product and process innovation, but the partners involved influence the type of innovation obtained. González-Pernía et al. (2015) found that the greatest effect on product innovation occurred when the STI and DUI modes were combined. Hence, the greater the number of partners, the greater the innovation output. However, they found the greatest effect on process innovation when the combination included DUI and STI partners, yet omitted universities. Therefore, it can be concluded that some studies show that a combination of both modes of innovation results in higher innovation, though more partners in each mode does not necessarily imply better results.

In terms of whether modes of innovation have an influence on radical and incremental results, Grillitsch \& Trippl (2014) found that industries with a synthetic knowledge base, which tend to apply a DUI mode of innovation, generated more incremental innovations. However, Fitjar \& Rodríguez-Pose (2013) found that both STI and DUI modes of interaction can produce both incremental and radical innovations. Radical product innovation is obtained when firms cooperate with suppliers, customers and universities, while radical process innovation occurs when firms cooperate with suppliers and research institutes. Therefore, these studies also show that having more partners in each mode does not necessarily imply better innovation results.

Does a combination of STI and DUI generate higher innovation performance than applying one mode on its own? The most recent literature, linked to evolutionary 
This is an Accepted Manuscript of an article published by Taylor \& Francis in Knowledge Management Research \& Practice, on 22/04/2019, available online: https://www.tandfonline.com/doi/abs/10.1080/14778238.2019.1601505

Please, cite as: Blanca de Miguel Molina, Rafael Boix Domenech \& María de Miguel Molina (2019) Analysing innovation in museums through qualitative comparative analysis, Knowledge Management Research \& Practice, 17:2, 213-226, DOI: 10.1080/14778238.2019.1601505

concepts, has focused on the combination of these bases, in what Boschma calls a combinatorial approach or DKB (Diversified Knowledge Bases) 2.0. As in the knowledge base studies, there are works which analyse the effect on innovation when STI and DUI modes appear on their own and when combined (Hauge et al., 2017; Galletto \& Boix, 2014). For example, some works have analysed whether the STI or DUI modes of innovation affect the innovation performance of firms. Results indicate there is higher innovation performance when modes of innovation are used - on their own or together - than when none of them is used (Jensen al., 2017). Other studies have analysed whether the impact on innovation depends on the modes used, although results are contradictory. For example, Apanasovich, Alcalde Heras, \& Parrilli (2016) found that the DUI mode had a higher effect on product innovation than the STI mode, when the two modes were analysed separately. Moreover, they found that the DUI mode on its own had a greater impact than when it was combined with the STI mode when organisational innovation was considered. However, Parrilli \& Alcalde Heras (2016) found that STI had a greater effect on product and process innovation, whereas the DUI mode had a greater influence on non-technological innovations. They concluded that both modes are necessary and that focusing only on the DUI mode, usually the mode most commonly adopted by firms, would have poorer results on technological innovations (product and process). Differences between studies might come from the fact that every study deals with different countries.

Results also differ according to the study, when these focus on combinations of the two modes. However, the majority of authors conclude that combining the two modes gives a higher innovation output (Jensen et al., 2007; Nunes \& Lopes, 2015; Tödtling \& Grillitsch, 2015; Apanasovich et al., 2016; Parrilli \& Alcalde-Heras, 2016; Thomä, 2017). For example, Jensen et al. (2007) and Parrilli \& Alcalde-Heras (2016) discovered that firms combining the two modes obtained better results than those relying on one mode, independently of the mode. González-Pernía et al. (2015) found that a combination of STI and DUI modes improved both product and process innovation, although results changed when some STI interactions were considered (universities). In this case, the impact was lower than when only one mode of innovation was applied (DUI mode in process innovation). Aslesen \& Pettersen (2017) indicated that firms start with a DUI or STI mode in the initial stages of innovation. Then, they have to combine both modes at later stages of innovation. Firms using the DUI mode look for more scientific knowledge outside the company, while those using the STI mode look to the DUI mode to market the results from innovations. Isaksen \& Nilsson (2013) advocated for policies that promote combinations of the two modes, building the absorptive capacity of DUI firms (to increase scientific competencies) and implementing the capacity of STI firms (to increase market competence).

The combinatorial approach has focused on combinations between knowledge bases, but has versed very little about how combination within the knowledge bases themselves increases the innovative capacity of companies, organizations and industries (Boschma, 2018), and how combinations between and within knowledge bases and 
This is an Accepted Manuscript of an article published by Taylor \& Francis in Knowledge Management Research \& Practice, on 22/04/2019, available online: https://www.tandfonline.com/doi/abs/10.1080/14778238.2019.1601505

Please, cite as: Blanca de Miguel Molina, Rafael Boix Domenech \& María de Miguel Molina (2019) Analysing innovation in museums through qualitative comparative analysis, Knowledge Management Research \& Practice, 17:2, 213-226, DOI: 10.1080/14778238.2019.1601505

innovation modes work simultaneously. This would be one of the most promising fields of study right now, especially in industries which could merge the three types of knowledge bases.

How do STI and DUI affect innovation in creative industries? Literature focusing on these two modes of innovation in the creative industries is really scarce. The results of the study by Isaksen \& Trippl (2017) suggest that the DUI mode dominates in cultural and creative industries. However, from other research, such as the work by Parrilli \& Alcalde Heras (2016), we can infer that the STI mode is more likely to generate process innovations, although when both modes of interaction are present, innovation performance will be higher. Moreover, the studies analysed indicate that having more partners in each mode of innovation does not guarantee higher innovation performance. Therefore, based on the conclusions obtained from the literature review of the two modes of innovation, the following hypotheses are stated:

Hypothesis 3. Museums are more likely to innovate if they cooperate with partners that use both the STI and DUI modes of innovation rather than if they only cooperate with partners that only use one mode (STI or DUI).

Hypothesis 4. Museums are not more likely to innovate when there is variety of partners in each mode of innovation.

HERE TABLE 3, please

\section{Methodology}

\section{Data and variables}

The data used in the analysis was quantitative and was obtained through a survey answered by 167 museums located in 43 countries. The questionnaire was an adaptation of the Community Innovation Survey (CIS) covering restoration and conservation activities undertaken by museums. The survey was sent in 2011 to 900 museums with paintings in their permanent collection. Only 90 museums out of the 167 museums that answered had a restoration and conservation department and carried out restorations. Moreover, 81 of these 90 museums were involved in innovations, although one of them indicated that it innovated even though it did not restore artworks. Therefore, the results in this paper are based on the 90 museums with restoration departments and on the 80 museums out of the 90 which undertook innovations (excluding the museum which indicated it innovated though it did not restore artworks). These museums were located in Europe (68), Canada and United States (11), Latin America (3), Asia (2) and Africa (3). Table 4 presents the number of museums according to the variables used in the analysis. Data indicates that a high number of museums combined symbolic and analytical knowledge bases, as well as the STI and DUI modes of interaction related to 
This is an Accepted Manuscript of an article published by Taylor \& Francis in Knowledge Management Research \& Practice, on 22/04/2019, available online: https://www.tandfonline.com/doi/abs/10.1080/14778238.2019.1601505

Please, cite as: Blanca de Miguel Molina, Rafael Boix Domenech \& María de Miguel Molina (2019) Analysing innovation in museums through qualitative comparative analysis, Knowledge Management Research \& Practice, 17:2, 213-226, DOI: $10.1080 / 14778238.2019 .1601505$

innovation.

\section{HERE TABLE 4, please}

The variables defined in the survey and used in the analysis are shown in greater detail in Table 5. These variables were:

- The types of innovations: eight types of innovations were defined for restoration and conservation activities. These types of innovations were defined taking into account the processes followed in the conservation and restoration of artworks (examining, analysing, preservation and restoration). Innovation was defined as high when museums undertook at least 50 per cent of the types of innovation (4 or more from 8).

- The knowledge bases: following Asheim \& Hansen (2009), symbolic, analytical and synthetic knowledge bases were taken into account. The line of reasoning followed by some authors considers occupation data to be a better measure (Manniche et al., 2017). In the case of their studies, this line of reasoning is correct for the fields they focus on, yet these studies cover entire regions and industries. By contrast, our study is focused on a specific department in a museum. Analysing this department in a museum is like examining the R\&D department in a firm. Chemists, physicists, biologists, engineers and restorers are hired due to their background. Therefore, we follow Müller et al. (2009) and Plum \& Hassink (2014), who considered university degrees to be useful measures for knowledge bases.

- Cooperation with other museums, universities, restoration institutes and specialist companies on innovation projects. Following Jensen et al. (2007) and Fitjat \& Rodríguez-Pose (2013), cooperation was divided into the STI mode and the DUI mode, and the four types of cooperation analysed were organised according to these authors' findings.

\section{HERE TABLE 5, please}

\section{Data analysis}

Our data analysis was undertaken using Qualitative Comparative Analysis (QCA), with fsQCA software (Ragin \& Davey, 2016). The QCA method enables complex causation to be analysed, that is, "an outcome may follow from different combinations of causal conditions" (Ragin, 2008). The advantage of QCA is that combinations of causal conditions can be analysed, instead of having to analyse every condition individually. Moreover, QCA enables conclusions to be drawn as to whether the selected conditions are necessary or sufficient to obtain an output (Mol \& Birkinshaw, 2014). 
This is an Accepted Manuscript of an article published by Taylor \& Francis in Knowledge Management Research \& Practice, on 22/04/2019, available online: https://www.tandfonline.com/doi/abs/10.1080/14778238.2019.1601505

Please, cite as: Blanca de Miguel Molina, Rafael Boix Domenech \& María de Miguel Molina (2019) Analysing innovation in museums through qualitative comparative analysis, Knowledge Management Research \& Practice, 17:2, 213-226, DOI: 10.1080/14778238.2019.1601505

A condition (X) is sufficient when cases show it is present together with the outcome (Y). Schneider \& Wagemann (2013) express it as "if X, then Y", "X implies $Y$ ", or "X is a subset of $Y$ ". For example, if the analytical base is present, the output takes value of 1 and reflects the presence of innovation.

Conversely, a condition (X) is necessary if when the output (Y) is present, then $X$ must also be present. Schneider \& Wagemann (2013) stated it as "if $Y$, then X", "Y implies X", or "Y is a subset of X". For example, if there is innovation the output is 1 and then the condition (e.g. the analytical base) is also 1 .

In this paper, we used QCA to analyse whether innovation undertaken by museums in their conservation and restoration departments was associated with knowledge bases and modes of innovation. The analysis was developed in two phases: the first focused on a crisp-set analysis (values 1 and 0 for conditions and output), using the 90 museums which had a restoration department. The objective was to obtain which causal conditions - or combination of them - explained that some museums were included in the innovative set (Model 1) and in the high innovation set (Models 2 and 3 ). The second phase used a fuzzy-set analysis and considered only the 80 museums which innovated in restoration. The objective of this analysis was to explain which causal conditions or combination of them were required to obtain a higher variety of innovations (Model 4). Therefore, three models were defined for analysing data and testing the three hypotheses defined in section 2.

The first model included the presence of innovation (INNOVY) as an output, and analysed the combination of six causal conditions in relation to the output. All the causal conditions in Model 1 were calibrated as crisp sets because the values used were 1 and 0 . In this model, the cases analysed were the 90 museums with restoration and conservation departments and the causal conditions were:

(1) The presence of an analytical knowledge base in combination with a symbolic base (AnalytY)

(2) The presence of a synthetic knowledge base in combination with a symbolic base (SynthY),

(3) The presence of a symbolic knowledge base on its own (SymbOnlyY)

(4) The presence of cooperation with partners only using the STI mode of innovation (OnlySTI),

(5) The presence of cooperation with partners only using the DUI mode of innovation (OnlyDUI),

(6) The presence of cooperation with partners using both the STI and DUI modes of innovation (STI\&DUI).

Model 1, expressing the presence of innovations, was defined as: 
This is an Accepted Manuscript of an article published by Taylor \& Francis in Knowledge Management Research \& Practice, on 22/04/2019, available online: https://www.tandfonline.com/doi/abs/10.1080/14778238.2019.1601505

Please, cite as: Blanca de Miguel Molina, Rafael Boix Domenech \& María de Miguel Molina (2019) Analysing innovation in museums through qualitative comparative analysis, Knowledge Management Research \& Practice, 17:2, 213-226, DOI: 10.1080/14778238.2019.1601505

$$
\text { INNOVY = f(AnalytY, SynthY, SymbOnlyY, OnlySTI, OnlyDUI, STI\&DUI) }
$$

The second model included the presence of high innovation (HIGHINNOVY) as an output, which meant that the museum had innovated in four or more different types of innovations. The causal conditions were the same conditions as those included in Model 1, all of which were calibrated as crisp sets because the values used were 1 and 0 . In this model, the cases analysed were also the 90 museums with restoration and conservation departments. The analysis for the presence of $Y$ was carried out to explain high innovation. Therefore, Model 2 expressing the presence of high innovation was defined as:

\section{HIGHINNOVY = f(AnalytY, SynthY, SymbOnlyY, OnlySTI, OnlyDUI, STI\&DUI)}

On the other hand, the third model was restricted to the analysis of the 80 museums which indicated they had innovated. The output was the variable INNOVf, which was a fuzzy set, calibrated as shown in Table 6 . This variable showed the count of types of innovation that each museum obtained. Moreover, the model analysed the combination of four causal conditions in relation to this output. These causal conditions were (Table 6):

(1) The count of analytical knowledge bases, calibrated as fuzzy sets (TAnalytf),

(2) The existence of symbolic knowledge bases, calibrated as fuzzy sets (TSymbf),

(3) The count of the two types of cooperation with partners using the STI mode of innovation, calibrated as fuzzy sets (STImodef),

(4) The count of the two types of cooperation with partners using the DUI mode of innovation, calibrated as fuzzy sets (DUImodef),

Model 3, expressing the count of innovations, was defined as:

$$
\text { INNOV } f=\mathrm{f}(\text { TAnalyt } f, \text { TSymb } f, \text { STImode } f \text {, DUImode } f \text { ) }
$$

Table 6 includes the calibration of the output and causal conditions used in Model 3. The output and the four causal conditions were calibrated as fuzzy sets due to the fact that the values used for them were counts. In these cases, the calibration method used was the direct method (Ragin, 2008), thus enabling the threshold for full membership, non-membership and the crossover point to be determined. The threshold for full membership calibration was made using the percentile 75 (quartile 3). For the crossover point, the value nearest the quartile 2 (median) and the average were used. Finally, for non-membership, the minimum value (quartile 0 ) was used. 
This is an Accepted Manuscript of an article published by Taylor \& Francis in Knowledge Management Research \& Practice, on 22/04/2019, available online: https://www.tandfonline.com/doi/abs/10.1080/14778238.2019.1601505

Please, cite as: Blanca de Miguel Molina, Rafael Boix Domenech \& María de Miguel Molina (2019) Analysing innovation in museums through qualitative comparative analysis, Knowledge Management Research \& Practice, 17:2, 213-226, DOI: 10.1080/14778238.2019.1601505

Once calibration had been computed, the necessary and sufficient combination of the causal conditions was obtained for the three models, and the results for intermediate and parsimonious solutions were used to present the results in Section 4. The analysis of necessary conditions was carried out using the option available in the fsQCA software for establishing each causal condition separately and for the output of each model. To consider that a condition is necessary, consistency values have to be higher than 0.90 (Mol \& Birkinshaw, 2014). The four hypotheses to be tested through the three models were defined in section 2.

\section{Results}

This section includes the analysis of how different causal conditions influenced innovation undertaken by museums, in relation to restoration and conservation. As we had defined three models and four hypotheses, we analysed every model separately, and the hypotheses were tested for the three models. Therefore, the following steps in the QCA for each model, using the fsQCA software, were:

(1) To analyse whether some of the causal conditions were necessary,

(2) To extract the truth table, and

(3) To analyse sufficiency through parsimonious and intermediate solutions using the configuration designed by Ragin \& Fiss (2008) to differentiate between core and complementary causal conditions.

Tables 7 and 8 include the results for the analyses of necessary and sufficient conditions for the three models defined. Before the two tables, the results for each model and hypothesis are explained.

\section{Results for Model 1: explaining innovation}

Model 1 relates the probability of being innovative with the presence of the knowledge bases and the modes of innovation in the restoration and conservation departments of the museums analysed. Results indicate that none of the knowledge bases and modes of innovation are necessary conditions ${ }^{1}$ for innovation and that any of the three following combinations of causal conditions is sufficient (Table 8):

Solution 1: AnalytY (symbolic and analytical) $\rightarrow$ INNOVY

\footnotetext{
${ }^{1}$ Results in Table 7 indicate consistency values are lower than 0.9 for each condition.
} 
This is an Accepted Manuscript of an article published by Taylor \& Francis in Knowledge Management Research \& Practice, on 22/04/2019, available online: https://www.tandfonline.com/doi/abs/10.1080/14778238.2019.1601505

Please, cite as: Blanca de Miguel Molina, Rafael Boix Domenech \& María de Miguel Molina (2019) Analysing innovation in museums through qualitative comparative analysis, Knowledge Management Research \& Practice, 17:2, 213-226, DOI: $10.1080 / 14778238.2019 .1601505$

\section{Solution 2: SymbOnlyY * OnlySTI $\rightarrow$ INNOVY \\ Solution 3: SymbOnlyY * (STI\&DUI) $\rightarrow$ INNOVY}

1. The combination of symbolic and analytical knowledge, that is, the unrelated variety of the two bases. As every museum showed the presence of symbolic knowledge, the presence of analytical knowledge has been considered in this paper as the presence of a combination of the two bases.

This solution confirms Hypothesis 1 (H1), which stated that museums are more likely to innovate when the two knowledge bases are present (unrelated variety). This solution also confirms previous works like the one by Grillitsch et al. (2017) for noncreative industries.

$2 \& 3)$ When symbolic knowledge appears on its own, museums need to cooperate with actors using the STI mode or with actors using both STI and DUI modes. The former indicates that the presence of the STI mode of interaction on its own can explain the presence of innovation. The latter shows that the presence of innovation can also be explained by the combination of the DUI and STI modes. These results are in line with those of Parrilli \& Alcalde Heras (2016), and other works in confirming greater innovation when the two modes are combined (see Section 2). However, as we aimed to demonstrate the presence of innovation and not the degree of innovation, the solutions in Table 8 prove that innovation appears both when museums cooperate with actors only using the STI mode and when interactions occur with actors using both the STI and DUI modes.

Therefore, $\mathrm{H} 3$ is not confirmed for this model, as the combination of the two modes is not required to state that museums are more likely to innovate.

\section{Results for Model 2: explaining high innovation}

In this section, the same process was followed as in Model 1, except that in this case, the output was high innovation.

Model 2 relates the probability of being highly innovative with the presence of the knowledge bases and the modes of innovation in the restoration and conservation departments of the museums analysed. The results show that to be highly innovative, the presence of an analytical knowledge base combined with a symbolic base is necessary ${ }^{2}$. The sufficient causal condition also involves the presence of an analytical

\footnotetext{
${ }^{2}$ There was only one variable for which the consistency value was higher than 0.90 , i.e. the presence of an analytical knowledge base combined with a symbolic base. Therefore, this
} 
This is an Accepted Manuscript of an article published by Taylor \& Francis in Knowledge Management Research \& Practice, on 22/04/2019, available online: https://www.tandfonline.com/doi/abs/10.1080/14778238.2019.1601505

Please, cite as: Blanca de Miguel Molina, Rafael Boix Domenech \& María de Miguel Molina (2019) Analysing innovation in museums through qualitative comparative analysis, Knowledge Management Research \& Practice, 17:2, 213-226, DOI: 10.1080/14778238.2019.1601505

knowledge as well as the absence of DUI or the combination of STI with DUI (Table $8)^{3}$.

When comparing the solution for models 1 and 2, the importance of the analytical knowledge base is also visible in Table 8. Moreover, the solution indicates that there would be high innovation even if there were no cooperation related to the DUI mode or related to the combination of the STI and DUI modes. This solution might indicate that the analytical base has greater influence on higher innovation than the modes of cooperation. The results confirm the conclusions reached by works that found that analytical knowledge has a greater impact on innovation than synthetic and symbolic bases on their own, but that unrelated variety, including a combination of analytical and symbolic bases, exerts a greater effect on innovation (Herstad et al., 2014; Pina \& Tether, 2016; Grillitsch et al., 2017).

In terms of the hypotheses defined in Section 2, only H1 (higher innovation when analytical and symbolic knowledge are combined) was confirmed.

\section{Results for Model 3: explaining innovation counts}

In Model 3, the analysis used the count of innovations as output, and the causal conditions were the counts for the types of knowledge bases (related variety of qualifications in each knowledge base), and for the STI and DUI modes (variety of partners in each mode of innovation).

The results show that there are no necessary conditions among the four included in the model ${ }^{4}$. The results also indicate that, among the knowledge bases, only the counts of analytical bases (Chemistry + Physics + Biology) is a sufficient condition to explain the number of innovations, which in addition is a core causal condition.

Moreover, the variety of STI and DUI modes (variety of partners in each mode) ${ }^{5}$ is also a sufficient condition.

causal condition is necessary to obtain high innovation results in museums, which means a higher variety of innovations undertaken by museums in relation to conservation and restoration. The rest of causal conditions were proved not to be necessary.

${ }^{3}$ Table 8 indicates that the solution has an overall consistency of $0.916(>0.80)$ whereas the solution coverage indicates that $20.37 \%$ of the outcome was covered by the solution term. The consistency value indicates that this combination is a sufficient causal condition to generate high innovation. However, due to the low solution coverage, the solution reached should not be considered as a definitive result and, therefore, additional analyses were undertaken with Model 3.

4 Consistency was below 0.9 in all the conditions.

5 The results in Table 8 indicate that the overall consistency of the solution was $0.84(>0.80)$ and the solution coverage implies that $54 \%$ of the outcome was covered by the solution. 
This is an Accepted Manuscript of an article published by Taylor \& Francis in Knowledge Management Research \& Practice, on 22/04/2019, available online: https://www.tandfonline.com/doi/abs/10.1080/14778238.2019.1601505

Please, cite as: Blanca de Miguel Molina, Rafael Boix Domenech \& María de Miguel Molina (2019) Analysing innovation in museums through qualitative comparative analysis, Knowledge Management Research \& Practice, 17:2, 213-226, DOI: 10.1080/14778238.2019.1601505

Therefore, we can conclude that $\mathrm{H} 2$ is proved through Model 3, which means that museums are more likely to innovate if there is related variety in the analytical knowledge base than if related variety appears in the symbolic base. The solution found also indicates that the higher the variety of modes of innovation (STI and DUI), the higher the variety of innovations. However, both modes appear as complementary causal conditions.

\section{HERE TABLE 7}

\section{HERE TABLE 8}

\section{Conclusions, limitations and future research directions}

The aim of this paper was to test what knowledge bases (analytical, synthetic, symbolic), innovation modes (STI, DUI) or combinations of both are necessary and sufficient to explain the presence of innovation and high innovation in the processes undertaken by museums through their restoration and conservation departments.

Two relevant findings were found:

First, in museums - an activity whose primary base is symbolic - both innovation and high innovation was explained by the combination of analytical and symbolic bases, this is, by unrelated variety. However, only the variety inside the analytical base was a sufficient condition to explain high innovation performance.

Second, the total number of innovations (counts) was higher when museums cooperated simultaneously with partners that used both modes of innovation (STI and DUI) compared to when they cooperated with partners that only used one of the modes, irrespective of whether there was a variety of partners in each mode.

Some of our findings are in line with Tödtling \& Grillitsch (2015) and Grillitsch et al. (2017) who found that a combination of analytical and symbolic bases increased innovation more than a sole analytical base; and that the combination of analytical knowledge and symbolic knowledge was higher than the effect of synthetic knowledge. Our results also agree with Parrilli \& Alcalde Heras (2016) in that innovation increases when both modes of innovation are involved.

This solution suggests that the higher the diversity of the analytical bases (related variety), the higher the variety of innovations. 
This is an Accepted Manuscript of an article published by Taylor \& Francis in Knowledge Management Research \& Practice, on 22/04/2019, available online: https://www.tandfonline.com/doi/abs/10.1080/14778238.2019.1601505

Please, cite as: Blanca de Miguel Molina, Rafael Boix Domenech \& María de Miguel Molina (2019) Analysing innovation in museums through qualitative comparative analysis, Knowledge Management Research \& Practice, 17:2, 213-226, DOI: 10.1080/14778238.2019.1601505

However, our methodology -based on crisp-set and fuzzy-set analyses- enables an analysis at the same time of the dichotomy between related and unrelated variety. The results go further than previous studies as they include the related variety of knowledge bases in an institution instead of the related variety that occurs between a firm and regional knowledge bases, which is the approach covered in literature (Tödtling \& Grillitsch, 2015; Grillitsch et al., 2017; Boschma, 2018; Květoň \& Kadlec, 2018).

Although studies about creative industries tend to state that they are characterised by a combination of symbolic and synthetic knowledge bases (Asheim \& Hansen, 2009; Klein, 2011; Van Tuijl \& Carvalho, 2014; Plum \& Hassink, 2014), in this paper we argue that in some activities, this combination (unrelated variety) mainly occurs between symbolic and analytical bases (Castro-Martínez, Recasens, \& JiménezSáez, 2013; Ingstrup et al., 2017). Therefore, in the conservation of restoration processes in museums, innovation is explained by the analytical knowledge base, both as unrelated variety (combined with the symbolic base) and as related variety (diversity of qualifications with analytical knowledge base).

Our results are also different from those of Fitjar \& Rodríguez-Pose (2013), as they found that including partners led to poorer innovation results. Conversely, we found that museums are more likely to innovate when they cooperate with partners using both modes of innovation.

Our results do not match either with Isaksen \& Trippl (2017), who says that the DUI mode is prevalent in the cultural and creative industries. Moreover, museums are more likely to innovate and to produce more innovations when there is a diversity of partners in each mode of innovation.

Results indicate that, although STI can occur on its own, the DUI mode needs the STI mode to be present. This result does not coincide with Isaksen \& Trippl (2017), who says that the DUI mode is dominant in the cultural and creative industries. Moreover, using more partners in each mode has a positive influence on innovation results. However, contrary to $\mathrm{H} 4$, it can be inferred that "museums are more likely to innovate when there is a diversity of partners in each mode of innovation".

Our results also provide some evidence that the mode of innovation in the creative industries might not fit well with the STI and DUI models, but could have its own characteristics, derived from the intense process of combination, recombination and the need for variety in these industries (see Johansson, 2004; Longo, Mariani, \& Mura, 2009).

Our research also has some limitations. One of them is the number of museums covered by the survey, considering that only $54 \%$ of the museums had a conservation and restoration department. This percentage might be explained by the high costs of 
This is an Accepted Manuscript of an article published by Taylor \& Francis in Knowledge Management Research \& Practice, on 22/04/2019, available online: https://www.tandfonline.com/doi/abs/10.1080/14778238.2019.1601505

Please, cite as: Blanca de Miguel Molina, Rafael Boix Domenech \& María de Miguel Molina (2019) Analysing innovation in museums through qualitative comparative analysis, Knowledge Management Research \& Practice, 17:2, 213-226, DOI: 10.1080/14778238.2019.1601505

having this type of department in a museum, as we realised when we contacted the museums that answered the survey. Qualitative Comparative Analysis is a methodology that works well with this number of cases, although, like other methods, it has its limitations. For example, as Ragin (2008) pointed out, the number of causal conditions should not be higher than eight. Moreover, the presence of the synthetic base was residual in the case analysed. Therefore, it was not possible to compare whether the results would be different in the case of a higher presence of this knowledge base.

Future research could cover more creative industries in which the combination of symbolic and analytical knowledge bases is essential. Analysing specific departments in these sectors might provide similar information to that obtained in this paper about knowledge bases and modes of innovation. Moreover, the methodology could be applied to other industries in order to obtain information about the importance of different combinations of knowledge bases and modes of innovation-

\section{References}

Apanasovich, N. (2016). Modes of Innovation: A Grounded Meta-Analysis. J Knowl Econ, 7, 720-737.

Apanasovich, N., Alcalde Heras, H., \& Parrilli, M. D. (2016). The impact of business innovation modes on SME innovation performance in post-Soviet transition economies: The case of Belarus. Technovation, 57/58, 30-40.

Asheim, B. (2007). Differentiated knowledge bases and varieties of Regional Innovation Systems. Innovation, 20(3), 223-241.

Asheim BT, Boschma R, \& Cooke P (2011) Constructing Regional Advantage: Platform Policies Based on Related Variety and Differentiated Knowledge Bases. Regional Studies, 45(7), 893-904.

Asheim, B. T. \& Coenen L. (2005) Knowledge bases and regional innovation systems: Comparing Nordic clusters. Research Policy, 34, 1173-1190

Asheim, B. \& Hansen, H. K. (2009). Knowledge Bases, Talents, and Contexts: On the Usefulness of the Creative Class Approach in Sweden. Economic Geography, 85(4), 425-442.

Aslesen, H. W. \& Pettersen, I. B. (2017). Entrepreneurial firms in STI and DUI mode clusters: do they need differentiated cluster facilitation? European Planning Studies, 25(6), 904-922.

Boschma, R. (2018). A Concise History of the Knowledge Base Literature: Challenging Questions for Future Research. In A. Isaksen, R. Martin, \& M. Trippl (Eds.) New Avenues for Regional Innovation Systems - Theoretical Advances, Empirical Cases and Policy Lessons, p. 23-40. Springer, Cham.

Castro-Martínez, E., Recasens, A., \& Jiménez-Sáez, F. (2013). Innovation systems in motion: an early music case. Management Decision, 51(6), 1276-1292.

Fitjar, R. D. \& Rodríguez-Pose, A. (2013). Firm collaboration and modes of innovation in Norway. Research Policy, 42, 128-138. 
This is an Accepted Manuscript of an article published by Taylor \& Francis in Knowledge Management Research \& Practice, on 22/04/2019, available online: https://www.tandfonline.com/doi/abs/10.1080/14778238.2019.1601505

Please, cite as: Blanca de Miguel Molina, Rafael Boix Domenech \& María de Miguel Molina (2019) Analysing innovation in museums through qualitative comparative analysis, Knowledge Management Research \& Practice, 17:2, 213-226, DOI: 10.1080/14778238.2019.1601505

Galletto, V. \& Boix R (2014). Distritos industriales, innovación tecnológica y efecto Idistrito: ¿Una cuestión de volumen o de valor?, Journal of Regional Research, 30, 27-51.

González-Pernía, J.L., Parrilli, M. D., \& Peña-Legazkue, I. (2015). STI-DUI learning modes, firm-university collaboration and innovation. $J$ Technol Transf, 40, 475492.

Grillitsch, M., Martin, R. \& Srholec, M. (2017). Knowledge Base Combinations and Innovation Performance in Swedish Regions. Economic Geography, 93(5), 458479.

Grillitsch, M. \& Trippl, M. (2014). Combining Knowledge from Different Sources, Channels and Geographical Scales. European Planning Studies, 22(11), 23052325.

Hauge, E. S., Kyllingstad, N., Maehle, N. \& Schulze-Krogh, A. C. (2017). Developing cross-industry innovation capability: regional drivers and indicators within firms. European Planning Studies, 25(3), 388-405.

Herstad, S. J., Aslesen, H. W., \& Ebersberger, B. (2014). On industrial knowledge bases, commercial opportunities and global innovation network linkages. Research Policy, 43, 495-504.

Hervas-Oliver, J.L., Sempere-Ripoll, F., Boronat-Moll, C., \& Rojas, R. (2015). Technological innovation without R\&D: unfolding the extra gains of management innovations on technological performance. Technology Analysis \& Strategic Management, 27(1), 19-38.

Hervas-Oliver, J.L., Sempere-Ripoll, F., Boronat-Moll, C., \& Rojas-Alvarado, R. (2018). On the joint effect of technological and management innovations on performance: increasing or diminishing returns? Technology Analysis \& Strategic Management, 30(5), 569-581.

Ingstrup, M.B., Jensen, S., \& Christensen, P. R. (2017). Cluster evolution and the change of knowledge bases: the development of a design cluster. European Planning Studies, 25(2), 202-220.

Isaksen, A. \& Nilsson, M. (2013). Combined Innovation Policy: Linking Scientific and Practical Knowledge in Innovation Systems. European Planning Studies, 21(12), 1919-1936.

Isaksen, A. \& Trippl, M. (2017). Innovation in space: the mosaic of regional innovation patterns. Oxford Review of Economic Policy, 33(1), 122-140.

Jensen, M. B., Johnson, B., Lorenz, E., \& Lundvall, B.A. (2007). Forms of knowledge and modes of innovation. Research Policy, 36, 680-693.

Johansson, F. (2004). The Medici effect: Breakthrough insights at the intersection of ideas, concepts, and cultures. Harvard Business School Press, Boston.

Klein, R. R. (2011). Where music and knowledge meet: a comparison of temporary events in Los Angeles and Columbus, Ohio. Area, 43(3), 320-326.

Květoň, V. \& Kadlec, V. (2018). Evolution of knowledge bases in European regions: searching for spatial regularities and links with innovation performance. European Planning Studies, DOI: 10.1080/09654313.2018.1464128. 
This is an Accepted Manuscript of an article published by Taylor \& Francis in Knowledge Management Research \& Practice, on 22/04/2019, available online: https://www.tandfonline.com/doi/abs/10.1080/14778238.2019.1601505

Please, cite as: Blanca de Miguel Molina, Rafael Boix Domenech \& María de Miguel Molina (2019) Analysing innovation in museums through qualitative comparative analysis, Knowledge Management Research \& Practice, 17:2, 213-226, DOI: 10.1080/14778238.2019.1601505

Laestadius, S. (2002). Biotechnology and the potential for a radical shift of technology in the Forest industry. In Carlsson, B. (ed.), Technology systems in the Bio industries. An international study (pp. 333-362). Springer Science + Business Media, New York.

Longo, M, Mariani, M. M., \& Mura, M. (2009). The effect of intellectual capital attributes on organizational performance. The case of the Bologna Opera House. Knowledge Management Research \& Practice, 7, 365-376.

Manniche, J. (2012). Combinatorial Knowledge Dynamics: On the Usefulness of the Differentiated Knowledge Bases Model. European Planning Studies, 20(11), 1823-1841.

Manniche, J., Moodysson, J., \& Testa, S. (2017). Combinatorial Knowledge Bases: An Integrative and Dynamic Approach to Innovation Studies. Economic Geography, 93(5): 480-499.

Martin, R, (2012). Measuring Knowledge Bases in Swedish Regions. European Planning Studies, 20(9), 1569-1582.

Martin, R, \& Moodysson, J, (2011), Comparing knowledge bases: on the geography and organization of knowledge sourcing in the regional innovation system of Scania, Sweden. European Urban and Regional Studies, 20(2), 170-187.

McIver, D., Fitzsimmons, S., \& Lengnick-Hall, C. (2019). Integrating knowledge in organizations: examining performance and integration difficulties. Knowledge Management Research \& Practice, 17(1), 14-23.

Mohammadi, A., Broström, A., \& Franzoni, C. (2017). Workforce Composition and Innovation: How Diversity in Employees' Ethnic and Educational Backgrounds Facilitates Firm-Level Innovativeness. J PROD INNOV MANAG, 34(4), 406426.

Mol, M. J., \& Birkinshaw, J. (2014). The Role of External Involvement in the Creation of Management Innovations. Organization Studies, 35(9), 1287-1312.

Moodysson, J., Coenen, L., \& Asheim, B. (2008). Explaining spatial patterns of innovation: analytical and synthetic modes of knowledge creation in the Medicon Valley life-science cluster. Environment and Planning A, 40, 10401056.

Müller, K., Rammer, C., \& Trüby, J. (2009). The role of creative industries in industrial innovation. Innovation: management, policy \& practice, 11, 148-168.

Nunes, S. \& Lopes, R. (2015). Firm Performance, Innovation Modes and Territorial Embeddedness. European Planning Studies, 23(9), 1796-1826.

OECD. (2015). Frascati Manual 2015: Guidelines for Collecting and Reporting Data on Research and Experimental Development, The Measurement of Scientific, Technological and Innovation Activities. OECD Publishing, Paris.

OECD/Eurostat. (2018). Oslo Manual 2018: Guidelines for Collecting, Reporting and Using Data on Innovation, 4th Edition, The Measurement of Scientific, Technological and Innovation Activities. OECD Publishing, Paris/Eurostat, Luxembourg.

Parrilli, M. D. \& Alcalde Heras, H. (2016). STI and DUI innovation modes: Scientifictechnological and context-specific nuances. Research Policy, 45, 747-756. 
This is an Accepted Manuscript of an article published by Taylor \& Francis in Knowledge Management Research \& Practice, on 22/04/2019, available online: https://www.tandfonline.com/doi/abs/10.1080/14778238.2019.1601505

Please, cite as: Blanca de Miguel Molina, Rafael Boix Domenech \& María de Miguel Molina (2019) Analysing innovation in museums through qualitative comparative analysis, Knowledge Management Research \& Practice, 17:2, 213-226, DOI: 10.1080/14778238.2019.1601505

Pina, K. \& Tether, B. S. (2016). Towards understanding variety in knowledge-intensive business services by distinguishing their knowledge bases. Research Policy, 45, 401-413.

Plum, O. \& Hassink, R. (2014). Knowledge bases, innovativeness and competitiveness in creative industries: the case of Hamburg's video game developers. Regional Studies, Regional Science, 1(1), 248-268.

Protogerou, A., Kontolaimou, A., \& Caloghirou, Y. (2017). Innovation in the European creative industries: a firm-level empirical approach. Industry and Innovation, 24(6), 587-612.

Ragin, C. (2008). Redesigning Social Inquiry. Fuzzy Sets and Beyond. University of Chicago Press, USA.

Ragin, C. C. \& Davey, S. (2016). Fuzzy-Set/Qualitative Comparative Analysis 3.0. Irvine, California: Department of Sociology, University of California.

Ragin, C. \& Fiss, P. (2008). Net effects versus configurations: an empirical demonstration co-authored with Peter Fiss. In C. Ragin (ed.): Redesigning Social Inquiry. Fuzzy Sets and Beyond (pp. 190-212). University of Chicago Press, USA.

Schneider, C. Q. \& Wagemann, C. (2013). Set-Theoretic Methods for the Social Sciences. A Guide to Qualitative Comparative Analysis. Cambridge University Press, United Kingdom.

Teixeira, S.J., Mota Veiga, P., \& Abreu Fernandes, C. (2019). The knowledge transfer and cooperation between universities and enterprises, Knowledge Management Research \& Practice, DOI: 10.1080/14778238.2018.1561166.

Thomä, J. (2017). DUI mode learning and barriers to innovation-A case from Germany. Research Policy, 46, 1327-1339.

Tödtling, F. \& Grillitsch, M. (2015). Does Combinatorial Knowledge Lead to a Better Innovation Performance of Firms? European Planning Studies, 23(9), 17411758.

Van Tuijl, E. \& Carvalho, L. (2014). Knowledge sourcing, knowledge bases, and the spatial organisation of car design. Environment and Planning A, 46, 1966 1982.

Table 1. Measuring knowledge bases

\begin{tabular}{|c|c|}
\hline Authors & Measure \\
\hline
\end{tabular}


This is an Accepted Manuscript of an article published by Taylor \& Francis in Knowledge Management Research \& Practice, on 22/04/2019, available online: https://www.tandfonline.com/doi/abs/10.1080/14778238.2019.1601505

Please, cite as: Blanca de Miguel Molina, Rafael Boix Domenech \& María de Miguel Molina (2019) Analysing innovation in museums through qualitative comparative analysis, Knowledge Management Research \& Practice, 17:2, 213-226, DOI: 10.1080/14778238.2019.1601505

\begin{tabular}{|c|c|c|}
\hline Asheim and Hansen (2009) & Occupation & $\begin{array}{l}\text { Analytical (such as physicists, } \\
\text { mathematicians and chemists) } \\
\text { Synthetic (such as architects, engineers, } \\
\text { and technicians) } \\
\text { Symbolic (such as writers, creative artists, } \\
\text { performing artists) }\end{array}$ \\
\hline Martin (2012) & Occupation & $\begin{array}{l}\text { Analytical (such as physicists, } \\
\text { mathematicians and chemists) } \\
\text { Synthetic (such as architects, engineers, } \\
\text { and technicians) } \\
\text { Symbolic (such as writers, creative artists, } \\
\text { performing artists) }\end{array}$ \\
\hline Herstad et al. (2014) & $\begin{array}{l}\text { Information } \\
\text { sources }\end{array}$ & $\begin{array}{l}\text { Analytical: use of scientific sources of } \\
\text { information } \\
\text { Synthetic: use of non-scientific sources } \\
\text { (customers, suppliers and competitors) }\end{array}$ \\
\hline Pina \& Tether (2016) & $\begin{array}{l}\text { Terms in } \\
\text { websites }\end{array}$ & $\begin{array}{l}\text { Analytical: terms like data, analytical, } \\
\text { analysis, measurement, laboratory, } \\
\text { research, and science. } \\
\text { Synthetic: terms like experience and } \\
\text { solutions. } \\
\text { Symbolic: terms like idea, art, studio, } \\
\text { music, designer, and creativity. }\end{array}$ \\
\hline Grillitsch et al. (2017) & Occupation & $\begin{array}{l}\text { Analytical: natural scientists. } \\
\text { Synthetic: engineers and technicians. } \\
\text { Symbolic: artists, designers, and } \\
\text { decorators. }\end{array}$ \\
\hline
\end{tabular}

Source: different sources

Table 2. Knowledge bases depending on the creative industry

\begin{tabular}{|lll|}
\hline Authors & Creative industry & Combination of knowledge bases \\
\hline $\begin{array}{l}\text { Asheim and Hansen } \\
(2009)\end{array}$ & Architecture & Symbolic and synthetic \\
\hline Klein (2011) & Music & Symbolic and synthetic \\
\hline $\begin{array}{l}\text { Castro-Martínez et al. } \\
(2013)\end{array}$ & Music & Analytical, symbolic, synthetic \\
\hline $\begin{array}{l}\text { Plum and Hassink } \\
(2014)\end{array}$ & Video games & $\begin{array}{l}\text { Symbolic and synthetic are dominant, } \\
\text { analytical is residual }\end{array}$ \\
\hline $\begin{array}{l}\text { Van Tuijl and } \\
\text { Carvalho (2014) }\end{array}$ & Design (cars) & Symbolic and synthetic \\
\hline Ingstrup et al. (2017) & Design & Analytical, symbolic, synthetic \\
\hline
\end{tabular}

Source: various sources

Table 3. Conceptualisation of the STI/DUI modes of innovation 
This is an Accepted Manuscript of an article published by Taylor \& Francis in Knowledge Management Research \& Practice, on 22/04/2019, available online: https://www.tandfonline.com/doi/abs/10.1080/14778238.2019.1601505

Please, cite as: Blanca de Miguel Molina, Rafael Boix Domenech \& María de Miguel Molina (2019) Analysing innovation in museums through qualitative comparative analysis, Knowledge Management Research \& Practice, 17:2, 213-226, DOI: 10.1080/14778238.2019.1601505

\begin{tabular}{|c|c|c|c|}
\hline $\begin{array}{l}\text { Mode of } \\
\text { innovation }\end{array}$ & Knowledge base & $\begin{array}{l}\text { Cooperation (mode } \\
\text { interaction*) }\end{array}$ & $\begin{array}{l}\text { Impact on } \\
\text { innovation }\end{array}$ \\
\hline None & & & $\begin{array}{l}\text { Lowest innovation } \\
\text { performance }\end{array}$ \\
\hline STI & Analytical & $\begin{array}{l}\text { STI-interaction: universities, } \\
\text { research centres, consultancy } \\
\text { firms }\end{array}$ & $\begin{array}{l}\text { Radical innovation, } \\
\text { new products, } \\
\text { processes. }\end{array}$ \\
\hline DUI & $\begin{array}{l}\text { Synthetic, } \\
\text { symbolic }\end{array}$ & $\begin{array}{l}\text { DUI-interaction: } \\
-\quad \text { Within the supply-chain: } \\
\text { suppliers, customers. } \\
-\quad \text { Outside the supply-chain: } \\
\text { competitors. }\end{array}$ & $\begin{array}{l}\text { Incremental } \\
\text { innovation, in } \\
\text { process, non- } \\
\text { technological } \\
\text { innovation. } \\
\end{array}$ \\
\hline STI + DUI & All & Both STI and DUI interactions & $\begin{array}{l}\text { Higher innovation } \\
\text { performance, } \\
\text { incremental, radical, } \\
\text { product, process. }\end{array}$ \\
\hline
\end{tabular}

Sources: *Fitjar and Rodríguez-Pose (2013); various sources

Table 4. Number of museums by variable analysed

\begin{tabular}{|l|c|c|c|}
\hline & The 90 museums & $\begin{array}{c}\text { The 80 museums } \\
\text { which innovated }\end{array}$ & $\begin{array}{c}\text { High innovation } \\
\text { (4 or more types of } \\
\text { innovation) }\end{array}$ \\
\hline Presence of & $\begin{array}{c}\text { Number of } \\
\text { museums }\end{array}$ & $\begin{array}{c}\text { Number of } \\
\text { museums }\end{array}$ & Number of museums \\
\hline $\begin{array}{l}\text { Only symbolic } \\
\text { knowledge base }\end{array}$ & 16 & 8 & 2 \\
\hline $\begin{array}{l}\text { Analytical and } \\
\text { symbolic knowledge } \\
\text { bases combined and }\end{array}$ & 74 & 71 & 52 \\
\hline $\begin{array}{l}\text { Synthetic knowledge } \\
\text { symbolic } \\
\text { bases combined }\end{array}$ & 4 & 4 & 8 \\
\hline $\begin{array}{l}\text { Only STI mode of } \\
\text { cooperation }\end{array}$ & 10 & 10 & 6 \\
\hline $\begin{array}{l}\text { Only DUI mode of } \\
\text { cooperation }\end{array}$ & 12 & 11 & 35 \\
\hline $\begin{array}{l}\text { STI \& DUI modes } \\
\text { combined }\end{array}$ & 52 & 50 & \\
\hline
\end{tabular}

Source: Own source compiled from survey results 
This is an Accepted Manuscript of an article published by Taylor \& Francis in Knowledge Management Research \& Practice, on 22/04/2019, available online: https://www.tandfonline.com/doi/abs/10.1080/14778238.2019.1601505

Please, cite as: Blanca de Miguel Molina, Rafael Boix Domenech \& María de Miguel Molina (2019) Analysing innovation in museums through qualitative comparative analysis, Knowledge Management Research \& Practice, 17:2, 213-226, DOI: $10.1080 / 14778238.2019 .1601505$

Table 5. Variables defined for the analysis

\begin{tabular}{|c|c|c|}
\hline $\begin{array}{l}\text { Name of the } \\
\text { variable }\end{array}$ & Explanation & Value \\
\hline $\begin{array}{l}\text { Innovation } \\
\text { output: } \\
\text { a) INNOV }\end{array}$ & $\begin{array}{l}\text { a) Types of innovation: } \\
- \text { In methods and instruments used } \\
\text { to examine and analyse art } \\
\text { objects }\end{array}$ & $\begin{array}{l}\text { Presence of (in the crisp } \\
\text { analysis): } \\
-\quad \text { INNOVY: Yes (1) or No (0) }\end{array}$ \\
\hline b) INNOVHIGH & 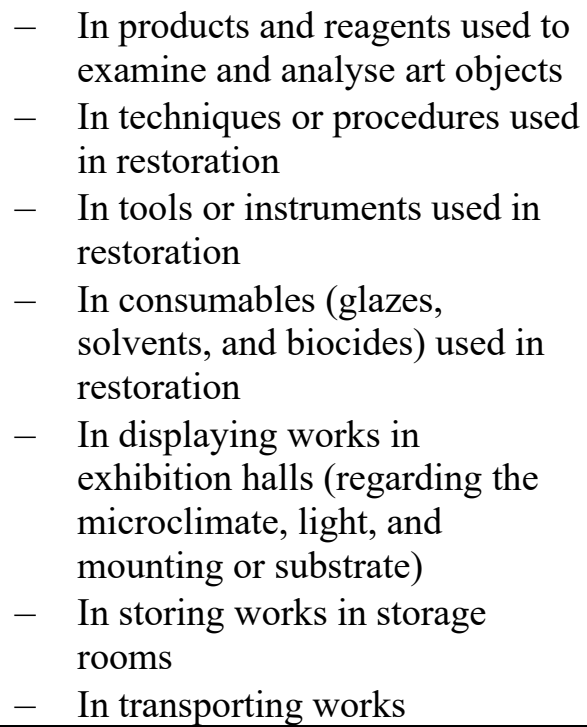 & $\begin{array}{l}- \text { HIGHINNOVY: } \geq \text { four } \\
\text { types of innovations, Yes }(1) \\
\text { or No }(0) \\
\text { Count of innovations (in the } \\
\text { fuzzy analysis): } \\
-\quad \text { INNOV: Types of } \\
\text { innovation }\end{array}$ \\
\hline Knowledge bases: & 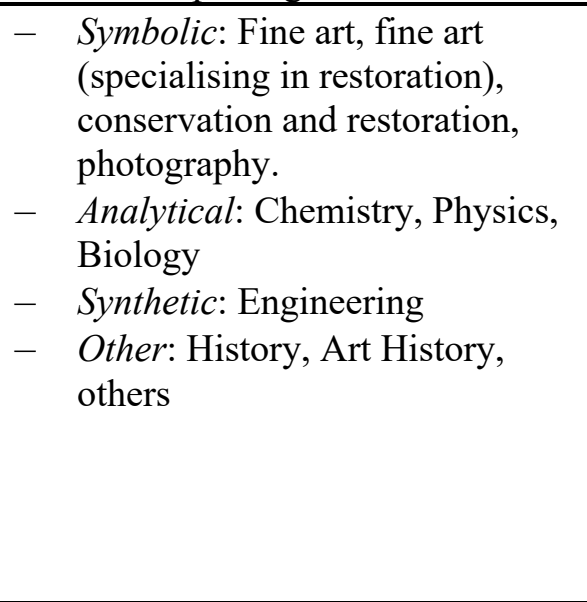 & $\begin{array}{l}\text { Presence of (in the crisp } \\
\text { analysis): } \\
-\quad \text { AnalytY: a combination of } \\
\text { symbolic and analytical, Yes } \\
\text { (1) or No (0). } \\
-\quad \text { SynthY: a combination of } \\
\text { symbolic and synthetic, Yes } \\
\text { (1) or No (0) } \\
-\quad \text { SymbOnlyY: only symbolic, } \\
\text { Yes (1) or No (0) } \\
\text { Count of (in the fuzzy analysis): } \\
-\quad \text { Types of analytical: TAnalyt } \\
-\quad \text { Types of symbolic: TSymb }\end{array}$ \\
\hline Cooperation: & $\begin{array}{l}\text { Presence of cooperation: } \\
\text { STI mode: }\end{array}$ & $\begin{array}{l}\text { Presence of (in the crisp } \\
\text { analysis): }\end{array}$ \\
\hline STI mode & - Universities & - OnlySTI: Yes (1) or No (0) \\
\hline b) DUI mode & $\begin{array}{l}-\quad \text { Research institutes } \\
\text { DUI mode: } \\
-\quad \text { Other museums } \\
-\quad \text { Specialist companies }\end{array}$ & $\begin{array}{l}-\quad \text { OnlyDUI: Yes (1) or No (0) } \\
-\quad \text { STI\&DUI: Yes (1) or No (0) } \\
\text { Count of (in the fuzzy analysis): } \\
-\quad \begin{array}{l}\text { STImode: types of STI mode } \\
\text { cooperation } \\
- \\
\text { DUImode: types of DUI } \\
\text { mode cooperation }\end{array}\end{array}$ \\
\hline
\end{tabular}


This is an Accepted Manuscript of an article published by Taylor \& Francis in Knowledge Management Research \& Practice, on 22/04/2019, available online: https://www.tandfonline.com/doi/abs/10.1080/14778238.2019.1601505

Please, cite as: Blanca de Miguel Molina, Rafael Boix Domenech \& María de Miguel Molina (2019) Analysing innovation in museums through qualitative comparative analysis, Knowledge Management Research \& Practice, 17:2, 213-226, DOI: $10.1080 / 14778238.2019 .1601505$

Source: Own source

Table 6. Calibration for the outcome and conditions for Model 3

\begin{tabular}{|c|c|c|c|c|c|}
\hline $\begin{array}{l}\text { Name for } \\
\text { variable }\end{array}$ & $\begin{array}{c}\text { Mea } \\
\text { n }\end{array}$ & $\begin{array}{l}\text { Std. } \\
\text { Dev. }\end{array}$ & \multicolumn{2}{|c|}{ Calibration } & \\
\hline \multicolumn{6}{|l|}{ Outcome } \\
\hline INNOVf & 4.6 & 2.1 & $\begin{array}{l}\text { Fuzzy } \\
\text { sets }\end{array}$ & $(6 ; 4.5 ; 1)$ & $\begin{array}{ll}\text { - } & \text { Full membership: quartile } \\
& \text { (percentile 75) } \\
- & \text { Crossover point: near the average } \\
- & \text { Non-membership: minimum value }\end{array}$ \\
\hline \multicolumn{6}{|l|}{$\begin{array}{l}\text { Causal } \\
\text { Conditions }\end{array}$} \\
\hline 1. TAnalyt $f$ & 1.688 & 0.943 & $\begin{array}{l}\text { Fuzzy } \\
\text { sets }\end{array}$ & $(2 ; 1.5 ; 0)$ & $\begin{array}{ll} & \text { Full membership: quartile } \\
& \text { (percentile 75) } \\
- & \text { Crossover point: near the average } \\
- & \text { Non-membership: minimum value } \\
\end{array}$ \\
\hline 2. $\mathrm{TSymb} f$ & 1.775 & 0.948 & $\begin{array}{l}\begin{array}{c}\text { Fuzzy } \\
\text { sets }\end{array}\end{array}$ & $(3 ; 1.5 ; 1)$ & $\begin{array}{ll}- & \text { Full membership: quartile } \\
& \text { (percentile 75) } \\
- & \text { Crossover point: near the average } \\
- & \text { Non-membership: minimum value } \\
\end{array}$ \\
\hline 3. $\quad$ STImode & 1.05 & 0.740 & $\begin{array}{l}\text { Fuzzy } \\
\text { sets }\end{array}$ & $(2 ; 1 ; 0)$ & $\begin{array}{ll}- & \text { Full membership: quartile } 3 \\
& \text { (percentile 75) } \\
- & \text { Crossover point: quartile 2 (median) } \\
- & \text { Non-membership: minimum value } \\
\end{array}$ \\
\hline $\begin{array}{ll}4 . & \text { DUImod } \\
\text { ef }\end{array}$ & 1.138 & 0.770 & $\begin{array}{l}\text { Fuzzy } \\
\text { sets }\end{array}$ & $(2 ; 1 ; 0)$ & $\begin{array}{ll}- & \text { Full membership: quartile } 3 \\
& \text { (percentile 75) } \\
- & \text { Crossover point: quartile 2 (median) } \\
- & \text { Non-membership: minimum value }\end{array}$ \\
\hline
\end{tabular}

Source: Table drawn up using fsQCA software

Table 7. Necessary conditions

\begin{tabular}{|l|c|c|c|c|}
\hline $\begin{array}{c}\text { Causal } \\
\text { condition }\end{array}$ & Consistency & Coverage & $\begin{array}{c}\text { Consistency } \\
\mathbf{> 0 . 9}\end{array}$ & $\begin{array}{c}\text { Necessary } \\
\text { condition? }\end{array}$ \\
\hline \multicolumn{5}{|c|}{ Model 1: Output INNOVY } \\
\hline AnalytY & 0.888889 & 0.972973 & NO & NO \\
\hline SynthY & 0.049383 & 1.000000 & NO & NO \\
\hline SymbOnlyY & 0.111111 & 0.562500 & NO & NO \\
\hline OnlySTI & 0.123457 & 1.000000 & NO & NO \\
\hline OnlyDUI & 0.135802 & 0.916667 & NO & NO \\
\hline STI\&DUI & 0.629630 & 0.980769 & NO & NO \\
\hline \multicolumn{7}{|c|}{ Model 2: Output HIGHINNOV } & YES \\
\hline AnalytY & 0.962963 & 0.702703 & YES & NO \\
\hline SynthY & 0.037037 & 0.500000 & NO & NO \\
\hline SymbOnlyY & 0.037037 & 0.125000 & NO & NO \\
\hline OnlySTI & 0.148148 & 0.800000 & NO
\end{tabular}


This is an Accepted Manuscript of an article published by Taylor \& Francis in Knowledge Management Research \& Practice, on 22/04/2019, available online: https://www.tandfonline.com/doi/abs/10.1080/14778238.2019.1601505

Please, cite as: Blanca de Miguel Molina, Rafael Boix Domenech \& María de Miguel Molina (2019) Analysing innovation in museums through qualitative comparative analysis, Knowledge Management Research \& Practice, 17:2, 213-226, DOI: 10.1080/14778238.2019.1601505

\begin{tabular}{|l|c|c|c|c|}
\hline OnlyDUI & 0.111111 & 0.500000 & NO & NO \\
\hline STI\&DUI & 0.648148 & 0.673077 & NO & NO \\
\hline \multicolumn{5}{|c|}{ Model 3: outcome INNOVf } \\
\hline TAnalyt $f$ & 0.829536 & 0.746598 & NO & NO \\
\hline TSymb $f$ & 0.495399 & 0.666175 & NO & NO \\
\hline STImodef $f$ & 0.668273 & 0.729665 & NO & NO \\
\hline DUImode $f$ & 0.718230 & 0.729255 & NO & NO \\
\hline TAnalyt $f$ & 0.829536 & 0.746598 & NO & NO \\
\hline
\end{tabular}

Source: Table drawn up using fsQCA software

Table 8. Sufficient conditions

\begin{tabular}{|c|c|c|c|c|c|}
\hline Output & \multicolumn{3}{|c|}{ INNOVY } & HIGHINNOV & INNOVf \\
\hline Configuration: crisp & \multicolumn{3}{|c|}{ Solutions Model 1} & Solution & Solution \\
\hline Conditions & S1.1 & S1.2 & S1.3 & S2.1 & S4.1 \\
\hline AnalytY & 0 & & & 0 & \\
\hline \multicolumn{6}{|l|}{ SynthY } \\
\hline SymbOnlyY & & - & ? & & \\
\hline \multicolumn{6}{|l|}{ OnlySTI } \\
\hline OnlyDUI & & & & $\otimes$ & \\
\hline STI\&DUI & & & 0 & $\otimes$ & \\
\hline \multicolumn{6}{|l|}{$\begin{array}{l}\text { Configuration: fuzzy } \\
\text { sets }\end{array}$} \\
\hline \multicolumn{6}{|l|}{ TAnalyt $f$} \\
\hline \multicolumn{6}{|l|}{ TSymbf } \\
\hline STImode $f$ & & & & & - \\
\hline DUImodef & & & & & $\bullet$ \\
\hline Cases & See Annex & $\begin{array}{c}\text { See } \\
\text { Annex }\end{array}$ & $\begin{array}{c}\text { See } \\
\text { Annex }\end{array}$ & See Annex & See Annex \\
\hline Consistency & 0.972973 & 1 & 1 & 0.916667 & 0.841281 \\
\hline Raw coverage & 0.888889 & 0.0246914 & 0.0246914 & 0.203704 & 0.541192 \\
\hline Unique coverage & 0.888889 & 0.0246913 & 0.0246913 & 0.203704 & 0.541192 \\
\hline Frequency cut-off & \multicolumn{3}{|c|}{2} & 2 & 4 \\
\hline Consistency cut-off & \multicolumn{3}{|c|}{0.916667} & 0.875 & 0.848469 \\
\hline Solution consistency & \multicolumn{3}{|c|}{0.974359} & 0.916667 & 0.841281 \\
\hline Solution coverage & \multicolumn{3}{|c|}{0.938272} & 0.203704 & 0.541192 \\
\hline & \multicolumn{3}{|c|}{ = Core causal condition present } & \multicolumn{2}{|c|}{$\bullet=\begin{array}{c}\text { Complementary causal } \\
\text { condition present }\end{array}$} \\
\hline & \multicolumn{3}{|c|}{$\otimes=$ Core causal condition absent } & \multicolumn{2}{|c|}{$\otimes=\begin{array}{c}\text { Complementary causal } \\
\text { condition absent }\end{array}$} \\
\hline & \multicolumn{3}{|c|}{ Blank spaces indicate "do not care" } & & \\
\hline
\end{tabular}

Source: Table drawn up using fsQCA software and following Ragin and Fiss (2008) 
This is an Accepted Manuscript of an article published by Taylor \& Francis in Knowledge Management Research \& Practice, on 22/04/2019, available online: https://www.tandfonline.com/doi/abs/10.1080/14778238.2019.1601505

Please, cite as: Blanca de Miguel Molina, Rafael Boix Domenech \& María de Miguel Molina (2019) Analysing innovation in museums through qualitative comparative analysis, Knowledge Management Research \& Practice, 17:2, 213-226, DOI: 10.1080/14778238.2019.1601505

\section{Annex}

Cases in Table 8:

(1) Cases in Model 1:

- S1.1: SA1 (1,1), SA2 (1,0), CA1 $(1,1)$, US1 $(1,1)$, US2 $(1,1)$, US3 $(1,1)$, US4 $(1,1), \operatorname{US} 5(1,1), \operatorname{US6}(1,1), \operatorname{US} 7(1,1), \operatorname{US} 8(1,1), \operatorname{US} 9(1,1)$, BR1 $(1,1)$, CL1 $(1,1)$, GU1 (1,1), JP1 $(1,1)$, TW1 $(1,1), \operatorname{AT} 1(1,1), \operatorname{AT} 2(1,1), \operatorname{BE} 1(1,1)$

- $\quad$ S1.2: DE19 $(1,1)$, HU2 $(1,1)$

- S1.3: AT3 $(1,1)$, CH5 $(1,1)$

(2) Cases in Model 2 (S2.1): SA1 (1,1), CL1 $(1,1)$, TW1 $(1,1)$, DE14 (1,1), GR2 $(1,1)$, PL3 (1,1), RO1 (1,1), SK1 (1,1), ES1 (1,1), ES5 (1,1), UK2 (1,1), AU1 $(1,0)$

(3) Cases in Model 3 (S3.1): SA3 (1,1), CA2 (1,1), AT3 (1,1), AT4 (1,1), DK1 $(1,1)$, DE1 $(1,1)$, DE4 $(1,1)$, DE5 $(1,1)$, DE11 $(1,1)$, DE13 $(1,1)$, IE1 $(1,0)$, NL1 $(1,1)$, CH5 $(1,1)$, AU2 $(1,1)$ 